\title{
Semantyczno-pragmatyczne znaczenie natury
}

Kategoria natury jest otwarta. Samo pojęcie „natura” legitymuje się bardzo starym rodowodem. Ani w przeszłości, ani obecnie nie posiada ono jednego sensu. Poszczególne nauki (filozoficzne, teologiczne, społeczne czy ścisłe) zawsze starały się ująć naturę w kategoriach wypracowywanych przez siebie koncepcji i dyskursów. Różnorodność stanowisk w tej kwestii jest ogromna. \wierdzę zatem, iż w swojej początkowej fazie dyskusja na temat natury domaga się precyzyjnego określenia samego terminu "natura” na poziomie semantycznym i pragmatycznym. Zabieg ten pozwoli uściślić, co faktycznie kryje się pod pojęciem „natura” (jakie jest jej odniesienie do rzeczywistości) oraz co rozumie człowiek gdy natrafia na pojęcie natury. Powyższe kwestie stanowić będą główny cel prowadzonych analiz.

\section{Poziom semantyczny natury}

W ujęciu semantycznym źródłosłowu "natura” należy szukać w językach indoeuropejskich. W istocie jest to przedsięwzięcie dla wytrawnego lingwisty. Dla obecnych potrzeb badawczych należy skoncentrować się jedynie na obszarze języka łacińskiego i greckiego. Szczególne greckie rozumienie pojęcia „natura” może okazać się tu bardzo pomocne.

W języku łacińskim termin "natura” wywodzi się od słowa nasci - rodzić się. Słownik Forcelliniego ${ }^{1}$ zwraca uwagę na następujące znaczenia terminu natura:

- w podstawowym tego słowa rozumieniu, „natura” oznacza urodzenie się, chwilę rodzenia, poród, powstawanie czegoś;

- w szerszym znaczeniu, to synonim terminu „życie”;

- w znaczeniu przenośnym, natura to organy (tak męskie jak i żeńskie) samego rodzenia, płodzenia;

- również w przenośni, natura pojmowana jako sposób odnoszenia się człowieka do praw wpisanych w naturę ludzką i naturę bytu;

- natura to właściwość, własność czegoś, siła i wrodzona jakiejś rzeczy, moc i władza - naturalna siła czegoś, własna istota duszy;

Por. hasło „natura” [w:] Forcellini A., Totius Latinitatis Lexicon, \: 4, Prati 1868, s. 231-232. 
- to założenie położenia, naturalne usytuowanie czegoś w terenie, ukształtowanie czegoś;

- wrodzone zdolności, stała cecha czegoś, talent, wrodzona obyczajom własność;

- natura w znaczeniu istoty bytu i ogarnięcia go umysłem;

- pojęcie pomocne dla określenia prawa boskiego i ludzkiego;

- natura jako początek i przyczyna sprawcza wszystkich rzeczy naturalnych; przez dawnych filozofów utożsamiana w tym ujęciu z Bogiem;

- w bardzo szerokim ujęciu natura jako określenie świata czy powszechności rzeczy;

- pojęcie natura używane szczególnie na określenie tego, z czego jakaś rzecz istotowo wewnątrz składa się - określenie istoty;

- natura jako określenie istoty Boga;

- określenie bytu lub istoty.

Sięgając z kolei do języka greckiego natrafiamy na termin physis (gr. phyo - stać się) będący synonimem łacińskiej „natury”. Słownik grecko-angielski Liddella i Scotta ${ }^{2}$ postrzega physis w różnych kontekstach. Omawiane pojęcie to początek, źródło pochodzenia, ale także naturalna forma lub istotne cechy osób lub rzeczy będące rezultatem rozwoju, wzrostu itp. Physis to również stały porządek przyrody. Kontekst filozoficzny ujawnia dodatkowe znaczenia omawianego terminu - physis jawi się jako siła twórcza, elementarna substancja. Jak zauważa G. Pellicer ${ }^{3}$, pierwotna zawartość treściowa jaką przypisuje mu Homer oznacza narodziny, wzrost (początkowo tylko roślin, a w następnych stuleciach już wszystkich istot żywych), rozmnażanie się bądź potomstwo. Physis to realna siła wszechświata, a dokładniej konglomerat spontanicznych (pozostających poza ludzką kontrolą) sił. One sprawiają, że rzeczy posiadają specyficzną wewnętrzną moc, dzięki której wynurzają się z obszaru nieistnienia, przekształcają, rozwijają itp. Innymi słowy, dla wczesnych myślicieli greckich, np. Homera czy Herodota, physis (natura) prezentuje podwójne oblicze. Pierwsze, natura to uniwersalna siła kosmosu, fundament świata; drugie, natura to istota realnego świata. Oba wymienione ujęcia zdają się ogniskować w pojęciu arche - fundamentalnej zasadzie (prawie), która unifikuje wszystkie elementy konstytuujące przyrodę.

2 Por. hasto „physis" [w:] Liddell H. G., ScotT R., Greek-English Lexicon, The Clarendon Press, Oxford 1940 (rep. 1958), s. 1964-1965.

3 Por. Pellicer G., Les débuts de „physis” (physis) et la notion de nature, „Bulletin de l'Université de \oulouse", 2 (1958), [s. 302-318.]; zob. także Ehrard J., Lidée de nature en France dans la première moitié du XVIII siècle, 囚: 1-2, Paris 1963; Gusdorf G., , Les sciences humaines et la pensée occidentale. Dieu, la nature, lhomme au siècle des lumières, Paris 1972; 凶ocanne B., Lidée de nature en France dans la seconde moitié du XVII siècle. Contribution á l'histoire de la pensée classique, Paris 1978. 
Zdaniem Kałuszyńskiej, dla takich filozofów jak np. Đales, Anaksymander Anaksymenes, arche to prasubstancja, pratworzywo świata, zasada jednocząca i organizująca całość zjawisk ${ }^{4}$. \akie rozumienie arche jako początku rzeczy, ich przyczyny sprawczej, podstawy wszelakich przemian itp. sprawia, iż physis zawiera w sobie obecne w świecie i już dostrzegane w tym czasie takie podstawowe idee składowe przyrody jak: dynamiczność (aktywność), wrodzoną spontaniczność, normatywność (postrzeganą jako kierunkowy rozwój), równoczesną zmienność i niezmienność, porządek etc.

Warto uczynić w tym miejscu jeszcze jedną uwagę metodologiczną. Bazując na kategorii greckiego physis, Rupert Sheldrake definiuje własne rozumienie tego co „fizyczne” i poddające się „fizykalnemu wyjaśnieniu”. Jego zdaniem, wiele zagadkowych zjawisk przyrodniczych (np. pole morfogenetyczne) podlega wyjaśnieniu fizykalnemu, ale owo wyjaśnienie nie zawsze mieści się w paradygmacie przyjętym przez obecną fizykę. W przekonaniu Sheldrake’a, wyjaśnienie może być natury fizykalnej w tym sensie, że „fizyczne” odniesione będzie nie do fizyki lecz do natury (physis). W takim ujęciu wszystko, co stanowi fragment natury jest fizyczne, chociaż nie wchodzi w skład współczesnej fizyki - jest natomiast częścią „fizyki natury”. Zjawiska mieszczące się w obszarze physis niejako automatycznie są także zjawiskami "normalnymi”, naturalnymi a nie „paranormalnymi”. Zdaniem Sheldrake’a, niedopuszczalne jest zatem zawężanie kategorii tego co „normalne” tylko i wyłącznie do możliwości eksplikacyjnych współczesnej nauki. W związku z powyższym, Sheldrake stawia trzy postulaty dotyczące metodologii badań naukowych. Pierwszy, poddanie badaniom tych obszarów rzeczywistości, które do tego czasu byly lekceważone, zaniedbane i traktowane przez naukę jako tabu. Drugi, zniesienie swoistego monopolu na prawo do badań naukowych, jaki przywłaszczyły sobie ośrodki akademickie. 『rzeci, potrzeba eksploracji idei istnienia inter-związków zarówno pomiędzy organizmami, jak i innymi składnikami grup społecznych, a także pomiędzy organizmami i ich środowiskiem naturalnym ${ }^{6}$.

\section{Poziom pragmatyczny natury}

Jak zauważa Stanisław Zięba, na poziomie pragmatycznym, dla wielu ludzi pojęcie „natura” to wygodny termin, swoisty wytrych myślowy, którym posługują się w sytuacji, gdy brak jest właściwego słowa dla precyzyjnego wyrażenia myśli.

4 Por. KaŁuszyńska E., Modele teorii empirycznych, Instytut Filozofii i Socjologii, Warszawa 1994, s. 18.

5 Por. Sheldrake R., Impossible ... for the Current Pfysics. Reply to the Open Letter by Giuseppe Sermoti, „Biology Forum”, vol. 98, 1996, [s.483-486] s. 483.

6 Por. 冈amże, s. 484. 
Konteksty w jakich następuje odwołanie się do natury są różne. Przykładowo, potocznie natura to coś materialnego, świat zewnętrzny, kosmos, otaczająca nas przyroda. Kontekst fizyczny ${ }^{7}$ ukazuje naturę z kolei jako synonim świata fizycznego, jednoznacznik właściwości energii i materii, moment konstelacji materii nieożywionej i ożywionej itp. Kontekst filozoficzny każe spojrzeć na naturę jako na całość rzeczy istniejących w czasie i przestrzeni. Kontekst ekologiczny przedstawia naturę jako całość składników tworzących ekosferę, zespół relacji, specyficznie zorganizowanych układów tworzących konkretne systemy biotyczne, np. las. W podobnym duchu wypowiada się o naturze Sheldrake ${ }^{8}$. Rozpatruje on naturę (przyrodę) w co najmniej w trzech aspektach. Pierwszy każe zwrócić uwagę na naturę jako wrodzoną dyspozycję typu „ludzka natura”. Drugie znaczenie natury wiąże się z ideą również wrodzonego bodźca lub siły. W takiej perspektywie natura (przyroda) jawi się jako twórcza i regulująca siła działająca w świecie fizycznym, bezpośrednia przyczyna wszystkich zjawisk. Skutkiem tego, natura (przyroda) staje się synonimem fizycznego świata jako całości. W przypadku trzeciego ujęcia mamy do czynienia ze zjawiskiem personifikacji natury, postrzeganej w tym kontekście jako Matka Natura, aspekt Wielkiej Matki, źródło i to co podtrzymuje życie, łono, do którego ono powróci.

$\mathrm{Na}$ jeszcze inne znaczenie natury wskazuje Christian Lévêque ${ }^{9}$. Jego zdaniem, natura to matryca, wzór, na którym rodzi się rzeczywistość. Wzór bakterii pozostaje niezmienny mimo, iż sama ulega zniszczeniu. \o samo dzieje się z człowiekiem, który jako jednostka, umiera, pozostaje jednak niezmienny wzór człowieka. Innymi słowy, natura to życie w nim samym - to co się rodzi, odradza w cyklach przyrody. \am gdzie jest natura, tam jest wzrost i dynamizm. Stanowi ona zatem istotę zjawisk, które powstają same z siebie w sposób spontaniczny, regularny, niezależny od wszystkich innych działań ludzkich czy boskich.

Spojrzenie na naturę jako wzór rzeczywistości ujawnia potrójną opozycję: naturalne-sztuczne, natura-kultura, natura-środowisko naturalne. W przypadku pierwszej opozycji natura (naturalne) to synonim tego co utworzone spontanicznie, samo z siebie. Gernot Böhme mówi wprost „[...] natura pojmowana jest jako to, co dane i godne zaufania, a jako takie również w pewnym stopniu miarodajne. Natura jest tym, co istnieje samo $z$ siebie, $w$ przeciwieństwie do tego, co wytwarzamy: natura jest tym, na czym można polegać; natura sama się reprodukuje, regeneruje"10. Jak jednak zauważa Geoffrey Lloyd, naturalność np. zjawisk

7 Por. ZięBa S., Historia myśli ekologicznej, Wydawnictwo KUL, Lublin 2004, s. 72.

8 Por. Sheldrake R., The Rebirth of Nature. The Greening of Science and God, Park Street Press, Rochester 1994, s. 10.

9 Por. LÉVÊQUE Ch., Quelles natures voulons-nous? Quelles natures aurons-nous?, [w:] Quelles natures voulons-nous? Pour une approche socio-écologique du champ de lenvironnment, (red.) LÉvÊQUe Ch., van der LeEuw S., Elsevier, Paris 2003, s. 19.

10 Böнme G., Filozofia i estetyka przyrody w dobie kryzysu środowiska naturalnego, przeł. J. Merecki, Oficyna Naukowa, Warszawa 2002, s. 86. 
przyrodniczych nie oznacza wcale, iż stanowią one wynik przypadkowych lub samowolnych działań, lecz występują regularnie i są rządzone przez możliwe do uchwycenia sekwencje przyczynowo-skutkowe ${ }^{11}$.

Sztuczne to wytworzone przez człowieka (np. w procesie tworzenia dzieła sztuki). W takim ujęciu - zdaniem Michała Hellera - „sztuka” dla Arystotelesa, a tym samym cała ludzka aktywność twórcza, staje się zasadą zewnętrzną w stosunku do bytu, a jego natura zasadą wewnętrzną ${ }^{12}$. Moim zdaniem, tak skonstruowana opozycja wydaje się być nieco arbitralna, albowiem sytuacja, gdy np. coś powstaje w wyniku zaistnienia mutacji (wywołanej czynnikami zewnętrznymi: niezależnymi bądź sprowokowanymi przez człowieka), nie poddaje się prostemu zakwalifikowaniu na naturalne i sztuczne. Poza tym, nawiązując już teraz do następnego rodzaju opozycji, w moim przekonaniu, technika, jako składowa kultury, posiada w swojej strukturze rodzaj tradycji mimesis - naśladowania przyrody. Jednakże zdaniem Böhmego, jeśli technika rzeczywiście potrafi naśladować przyrodę (a nie tylko realizować potencjalne możliwości), to każdy produkt techniki jest sztuczną naturą ${ }^{13}$. Według mnie, przymiotnik „sztuczny” ma tu drugoplanowe znaczenie - wskazuje np. inne źródło pochodzenia, a nie istotę sprawy.

Spróbujmy przeprowadzić następujący eksperyment myślowy. Gdy człowiek tworzy np. zupełnie nowe gatunki, lub gdyby udało się wytworzyć w warunkach laboratoryjnych, z użyciem wyrafinowanej techniki, „sztuczny” żywy organizm, to będzie on w istocie żywym organizmem, mającym takie samo życie jak każdy inny. W obu przypadkach istota (natura) życia pozostanie taka sama. W moim przekonaniu, działania człowieka mają odniesienie do realnej przyrody, a to co sztuczne poszerza dotychczasowy stan natury. W takiej sytuacji, mówienie o istotnych różnicach zachodzących pomiędzy „sztuczną naturą życia” a „naturalną naturą życia" stanie się, moim zdaniem, mocno problematyczne.

Druga opozycja (natura-kultura), ukazuje naturę jako źródło biologii. Kultura natomiast to tradycja przekazywana przez pokolenia. Problem w tym, iz w obszarze biologii mamy też do czynienia z pokoleniowym przekazem np. informacji genetycznej, a sam przekaz jest już rodzajem tradycji (łać. tradeo, trade$r e$ - przekazywać). Koncentrując uwagę na źródle przekazu tradycji-informacji, Böhme zwraca uwagę, iż natura stanowi normę dla techniki. Pozanaturalne nie są zatem wytwory kultury czy techniki jako takie, lecz tylko te, które nie traktują natury jako substancjalnej wartości, a więc tego co powinno być bezwzględnie

11 Por. LLoyd G.E.R., Nauka grecka. Od Talesa do Arystotelesa, przeł. J. Lesiński, Prószyński i S-ka, Warszawa 1998, s. 17.

12 Por. Arystoteles, Fizyka, II 192b (przeł. K. Leśniak, [w:] Arystoteles, Dzieła wszystkie, 囚: 2, PWN, Warszawa 1990); por. także Heller M., Filozofia przyrody. Zarys historyczny, Znak, Kraków 2004, s. 46.

13 Por. Böнme G., Filozofia i estetyka przyrody..., s. 174. 
zachowane jako dane. \akie kulturowe spojrzenie na naturę ukazuje ją jako rodzaj konwencji, a nie coś realnego, suwerennego itp. ${ }^{14}$. W przeciwnym wypadku, natura i kultura spotykają się niejako pośrodku w fenomenie „sztucznej natury” - moim zdaniem, substytucie utraconej bezpiecznej rzeczywistości. Dla cytowanego autora, „sztuczna natura” reprezentuje jakiś stan przejściowy, moment ewolucyjnej decyzji, stojącej przed człowiekiem. Ludzkość coraz wyraźniej dostrzega negatywne dla przyrody skutki swojej cywilizacyjno-kulturowej działalności. Jej dalsza egzystencja będzie się realizować w obecności różnorodnych zagrożeń. Marzenie o bezpiecznych światach stara się zatem urzeczywistniać poprzez natury zastępcze - nowe, zaplanowane i najlepiej takie, które nie zerwą łączności $\mathrm{z}$ dawną naturą. Zdaniem Böhmego, realizacja tak postawionego zadania może się dokonać na dwa sposoby: poprzez „techniki przymierza” lub supertechnologię ${ }^{15}$. Oba kierunki są współcześnie zauważalne, choć trudno jeszcze orzec, który zdobędzie dominację. W przypadku „techniki przymierza”, chodzi o akceptację przez rodzaj ludzki swojej naturalności i wprowadzenie takiego rodzaju technologii, który doprowadzi do harmonii pomiędzy naturą a techniką. Jeśli tak się stanie, to granica pomiędzy nimi może być bardzo umowna. W drugim przypadku, ludzkość zaneguje sens, potrzebę istnienia przyrody i postawi na supertechnologię. Sztuczna natura być może stanie się sposobem na ostatecznie zerwanie ze stanem natury, a tym samym na uniezależnienie się od przyrody. W tego rodzaju opcji, dyskusja o opozycji natura-kultura będzie - moim zdaniem - również problematyczna. Đrudno bowiem dyskutować na ten temat, gdy brak jest adwersarza, a jedynym dostępnym człowiekowi światem, jest świat kultury.

Drzecia opozycja (natura-środowisko naturalne) ukazuje jeszcze inne ujęcia. W tej perspektywie, natura jawi się jako życie dzikie, bez wpływu człowieka. Środowisko naturalne to obszar konieczny do rozwoju takiego życia. Wydaje się zatem, iż sfera gdzie człowiek zaznaczył swoją obecność nie jest już środowiskiem naturalnym. Nic bardziej mylącego. Człowiek jako gatunek biologiczny nie mógł się rozwijać bez swojego, jak najbardziej naturalnego, biologicznego zaplecza. Đaka sytuacja zasadniczo trwa do dziś. Mimo techniki, ludzkość nadal nie jest w stanie zerwać ze swoimi biologicznymi korzeniami - człowiek w dalszym ciągu „żyje w przepływie żywiołów”16. W życiu człowieka granica między tym co nazywamy środowiskiem naturalnym i sztucznym pozostaje rozmyta. \wierdzę tak, ponieważ obecne oddziaływanie człowieka na przyrodę jest bardzo silne i dociera do najodleglejszych zakątków globu. Siła antropopresji sprawia, że mówienie o dzikim życiu, środowisku naturalnym, etc. pozostaje rodzajem konwencji stylistycznej. W moim przekonaniu, nie mamy już do czynienia ze

\footnotetext{
Por. \amże, s. 178, 180.

5 Por \amże, s. 181-183.

16 冈amże, s. 125.
} 
środowiskiem naturalnym, lecz środowiskiem determinowanym zarówno przez czynniki biologiczne jak i społeczne. Sama natura jest zatem definiowana przez podwójny kompleks determinant: biologicznych i pozabiologicznych - staje się produktem społecznym ${ }^{17}$, a człowiek współtwórcą oraz uczestnikiem natury.

Rekapitulując dotychczasowe ustalenia, można powiedzieć za Stanisławem Ziębą, iż znaczenie pojęcia "natura” może być rozpatrywane z podwójnej perspektywy: statycznej i dynamicznej. Na podobne ujęcie natury, wskazuje również Słownik języka polskiego, gdzie natura ujmowana jest jako całokształt rzeczy, wszechświat, stan pierwotny, prymitywny, nie zmieniony przez cywilizację. Jednocześnie natura to także przyroda pojmowana jako siła ksztaltująca organizmy żywe, jako wrodzone własności, istota, główne, charakterystyczne rysy czegoś ${ }^{18}$.

Statyczne rozumienie natury ukazuje ją jako całość rzeczy istniejących, całość uporządkowaną, kosmos, otaczającą nas realną rzeczywistość itp. Natura w aspekcie statycznym jest ujmowana jako „sama w sobie” - istota bytu, zespół jego fundamentalnych własności. Warto podkreślić fakt obecnego w takiej naturze porządku. Böhme stwierdza bowiem jednoznacznie: „mówienie o naturze sugeruje istnienie danego porządku - czy to porządku kosmosu wraz z prawami przyrody, czy to porządku życia w jego biegu i współgraniu elementów organizmu. Również $w$ dziedzinach pośrednich, tj. dziedzinach między universum a indywidualnym organizmem, natura rozumiana jest jako porządek, jako ramy współgrania organizmów i żywiołów"19. Dla cytowanego autora, porządek istniejący w naturze jest godny zaufania, ponieważ jawi się jako bardziej skuteczny niż ten utworzony przez człowieka. Ludzkie zaufanie do natury nie jest jednak bezgraniczne, możemy je nazwać zaufaniem przez kontrolę ${ }^{20}$. Naturze ufamy bardziej niż technice, ale gdzie to możliwe (np. w medycynie) kontrolujemy ją za pomocą techniki. Być może powyższe względy sprawiają, iż ludzkość chce wpływać na przyrodę, a równocześnie powstrzymuje się przed realizacją planów całkowitej „humanizacji przyrody” i poddania jej pod bezpośredni ludzki nadzór. Ponadto, odkrycie porządku w naturze jest dla Böhmego przesłanką tłumaczącą politykę ochrony środowiska naturalnego ${ }^{21}$.

Dynamiczne rozumienie natury wskazuje na physis jako na „zasadę aktywności" przyrody. Wspomniana zasada oznacza w praktyce nie tylko dynamiczne procesy fizyko-chemiczne. 囚o coś więcej. Natura jako zasada aktywności, to swo-

\footnotetext{
Por. 凶amże, s. 90.

18 Por. hasło „natura” [w:] Slownik jezzyka polskiego, (red.) SzymczaK M., 囚: 2, PWN, Warszawa 1988 , s. 298.

19 BöHme G., Filozofia i estetyka przyrody..., s. 101.

20 Por. 冈amże, s. 95.

21 Por. Øamże s. 102.
} 
isty punkt odniesienia różnorakich koncepcji (fizycznych, biologicznych, ekologicznych, społecznych, politycznych itp.), których podstawowym celem jest ukazanie struktury i praw zarządzających przyrodą ${ }^{22}$.

Wydaje się, iż w analizach na temat natury szczególnego podkreślenia wymaga również kontekst, nazwijmy go roboczo, antropologiczno-relacyjny. Dla Böhmego, relacja człowiek-przyroda jest czymś fundamentalnym. Paradoksalnie, istota owej relacji sprowadza się do stosunku człowieka do samego siebie. Jest tak, ponieważ wzmiankowana relacyjność może być rozpatrywana w podwójnym ujęciu: albo „od zewnątrz”, albo „od wewnątrz”. Na pierwszy (zewnętrzny) aspekt zwraca uwagę Böhme. W jego przekonaniu, przyroda-natura postrzegana jest jako coś, czym sami (jako ludzie) nie jesteśmy. Nasze ciała stanowią integralną cząstkę przyrody, to także integralna część nas samych, przy jednoczesnym braku utożsamienia człowieka z jego własnym ciałem. W relacji człowiek - przyroda, „ludzkie ciało jako natura jest traktowane jako coś zewnętrznego wobec człowieka"23. Drugie ujęcie relacji człowiek - przyroda (od wewnątrz), zdaje się być w opozycji do wcześniejszych ustaleń. Zdaniem Hansa Jonasa, ciało to przyroda, którą sami jesteśmy. ${ }^{24}$ Dzięki obdarzeniu ciałem, dysponujemy wiedzą o naturze - mamy wgląd w jej wewnętrzność. Ciało staje się naszą szczególną „własną naturą". Wobec powyższego, ludzka natura pretenduje do miana tego wszystkiego, co jak stwierdza Antonio Damasio, „odziedziczyliśmy pod postacią pakietu genetycznego”, jak i tego, „Co nabyliśmy w procesie rozwoju osobniczego poprzez interakcje ze środowiskiem społecznym, zarówno te przemyślane i zgodne z naszą wolą, jak i nieprzemyślane, bezwolne"25.

Dotychczasowe ustalenia badawcze zdają się potwierdzać opinię Zięby, iż z ludzkiego punktu widzenia, natura to kategoria mająca sens tylko w odniesieniu do człowieka. Natura to zespół treści odczytywanych przez człowieka w otaczającym świecie. Natura to rezultat mądrości ludzkiej, posiadanej wiedzy przyrodniczej, filozoficznej itp. ${ }^{26}$. Dak określona definicja robocza natury tłumaczy - moim zdaniem - dlaczego na przestrzeni całej historii myśli ludzkiej zawartość treściowa tego pojęcia zawsze była zmienna. Działo się tak, ponieważ wpływały na nią różne czynniki: epoki historyczne, prądy filozoficzne, czynniki religijne, trendy społeczne, strategie badawcze w nauce itp. Wydaje się zatem, iż - podążając za tokiem analiz poczynionych przez Ziębę - należy podjąć się próby charak-

22 Por. ZięBA S., Historia myśli ekologicznej, s. 73.

23 BöHme G., Filozofia i estetyka przyrody..., s. 128.

24 Por. Jonas H., Organismus und Freiheit, Vandenhoeck \& Ruprecht, Göttingen 1973, s. 142, 154.

25 Damasio A. S., Błąd Kartezjusza. Emocje, rozum i ludzki mózg, Rebis, Poznań 1999, s. 11.

26 Por. ZIĘBA S., Natura i czlowiek w ekologii humanistycznej, Zakład Ekologii Człowieka KUL, Lublin 1998, s. 88-90. 
terystyki natury w oparciu o proponowane kryteria: humanistyczno-kulturowe, filozoficzne, przyrodnicze, i ekologiczne ${ }^{27}$. Powyższe spectrum zagadnień, choć szerokie, prawdopodobnie nie udzieli ostatecznej odpowiedzi na pytanie o sens pojęcia natury. Nie mniej jednak, w moim przekonaniu, trzeba spróbować zgłębić, ten jeden $\mathrm{z}$ najbardziej podstawowych problemów badawczych.

\section{LIDERA冈URA}

ARYstoteles, Dzieła wszystkie, 冈: 2, PWN, Warszawa 1990.

Böнme G., Filozofia i estetyka przyrody w dobie kryzysu środowiska naturalnego, przeł. J. Merecki, Oficyna Naukowa, Warszawa 2002.

Damasio A. S., Blad Kartezjusza. Emocje, rozum i ludzki mózg, Rebis, Poznań 1999.

EhrARD J., L'idée de nature en France dans la première moitié du XVIII siècle, 囚: 1-2, Paris 1963.

Forcellini A., Totius Latinitatis Lexicon, \: 4, Prati 1868.

Gusdorf G., Les sciences humaines et la pensée occidentale. Dieu, la nature, l'homme au siècle des lumieres, Paris 1972.

Heller M., Filozofia przyrody. Zarys historyczny, Znak, Kraków 2004.

Jonas H., Organismus und Freiheit, Vandenhoeck \& Ruprecht, Göttingen 1973.

KaŁuszyŃska E., Modele teorii empirycznych, Instytut Filozofii i Socjologii, Warszawa 1994.冈

LÉVÊQUE Ch., Quelles natures voulons-nous? Quelles natures aurons-nous?, [w:] Quelles natures voulons-nous? Pour une approche socio-écologique du champ de lenvironnment, (red.) Lévêque Ch., van der Leeuw S., Elsevier, Paris 2003. s. 13-21.

Liddell H. G., Scott R., Greek-English Lexicon, The Clarendon Press, Oxford 1940 (rep. 1958).

LLoyd G.E.R., Nauka grecka. Od Talesa do Arystotelesa, przeł. J. Lesiński, Prószyński i S-ka, Warszawa 1998.

Pellicer G., Les débuts de „physis” (physis) et la notion de nature, „Bulletin de l'Université de Doulouse", 2 (1958), s. 302-318.

SHELDRAKe R., The Rebirth of Nature. The Greening of Science and God, Park Street Press, Rochester 1994.

Sheldrake R., Impossible ... for the Current Pfysics. Reply to the Open Letter by Giuseppe Sermoti, „Biology Forum”, vol. 98, 1996, s.483-486.

Stownik języka polskiego, (red.) Szymczak M., 囚: 2, PWN, Warszawa 1988.

\ocanne B., Lidée de nature en France dans la seconde moitié du XVII siècle. Contribution á l'histoire de la pensée classique, Paris 1978.

ZIĘBA S., Natura i człowiek w ekologii humanistycznej, Zakład Ekologii Człowieka KUL, Lublin 1998.

ZIĘBA S., Historia myśli ekologicznej, Wydawnictwo KUL, Lublin 2004.

27 Por. \amże, s. 261. 


\section{Semantic - pragmatic meaning of nature}

\section{SUMMARY}

Semantic meaning of the term "nature" comes from the Latin word "nasci” - "to get born", and Greek words "physis" and „arche". The substance of the latter two terms is fully explained in the Latin dictionary of A. Forcellini (囚otius Latinitatis Lexicon, $\nabla: 4$, Prati 1868, p. 231-232) and the Greek-English dictionary of H. G. Liddell and R. Scott (Greek-English Lexicon, The Clarendon Press, Oxford 1940, 1958, p. 1964-1965.).

Pragmatic sense of the term "nature" depends on the context (physical, philosophical, ecological, anthropological, relative, etc.). It can be also analyzed from two different perspectives: static and dynamic. This situation leads to the triple opposition: natural versus artificial, nature versus culture and nature versus environment. Ultimately, in the pragmatic sense, nature is a category making sense only in relation to the human being. Nature is a set of meanings registered by the human being in his world. Nature is a result of human wisdom and gained knowledge in science, philosophy and so on. Over the whole history of human thinking the true substance of this term has been always variable - determined by various factors: historic periods, philosophical and social trends, religions, different scientific exploration strategies, etc. 